$\underline{\text { Original Articles }}$

\title{
Prophylactic Administration of Doxycycline Reduces Central Venous Catheter Infections in Patients Undergoing Hematopoietic Cell Transplantation
}

Mohamed Baydoun, R.N., MSN. ${ }^{{ }^{*}}$, Zaher K. Otrock, M.D. ${ }^{{ }^{*}}$, Samar Okaily, R.N., MPH. ${ }^{1}$, Rita Nehme, R.N., BSN. ${ }^{1}$, Racha Abu-Chahine, R.N., MSN. ${ }^{1}$, Ali Hamdan, R.N. BSN. ${ }^{1}$, Samar Noureddine, R.N., Ph.D. ${ }^{2}$, Souha Kanj, M.D. ${ }^{3}$, Zeina Kanafani, M.D. ${ }^{3}$, Ali Bazarbachi M.D., Ph.D. ${ }^{1}$, Mohamed A. Kharfan-Dabaja, M.D. ${ }^{1}$

${ }^{1}$ Division of Hematology-Oncology and Bone Marrow Transplantation Program, American University of Beirut Medical Center, Beirut, Lebanon

${ }^{2}$ School of Nursing, American University of Beirut Medical Center, Beirut, Lebanon

${ }^{3}$ Division of Infectious Diseases, American University of Beirut Medical Center, Beirut, Lebanon

*MB and ZKO contributed equally to this manuscript

Correspondence to: Mohamed A. Kharfan-Dabaja, M.D., Department of Blood and Marrow Transplantation, Moffitt Cancer Center. 12902 Magnolia Drive, FOB-3, Tampa, FL, 33612, United States of America. Phone: +1813-745-8248. Fax: +1-813-745-8468. E-mail: mailto:Mohamed.Kharfan-Dabaja@moffitt.org

Competing interests: The authors have declared that no competing interests exist.

Published: February16, 2013

Received: December 12, 2012

Accepted: January 13, 2013

Citation: Mediterr J Hematol Infect Dis 2013, 5(1): e2013015, DOI: 10.4084/MJHID.2013.015

This article is available from: http://www.mjhid.org/article/view/11019

This is an Open Access article distributed under the terms of the Creative Commons Attribution License (http://creativecommons.org/licenses/by/2.0), which permits unrestricted use, distribution, and reproduction in any medium, provided the original work is properly cited.

Abstract. Hematopoietic stem cells are generally transfused through a central venous catheter (CVC), which also facilitates administration of medications and intravenous fluids. We had observed a high rate of CVC infections at our Bone Marrow Transplantation (BMT) unit. Accordingly, we evaluated the impact of administration of doxycycline as a prophylactic strategy to reduce CVC infection rates. Data was collected retrospectively on 54 consecutive patients, 26 who received doxycycline (doxycycline group), and we compared their outcomes to a previous cohort of 28 subjects who did not receive doxycycline (comparison group). The groups were comparable in regards to age, gender, transplant type, and CD34 cell dose. No (0\%) CVC infection was observed in the doxycycline group, while 5 infection episodes $(18 \%)$ occurred in 4 patients in the comparison group $(\mathbf{p}<0.001)$. Isolated organisms included: Escherichia-coli $(\mathrm{EC})=1$, coagulase-negative Staphylococcus-spp (CNSS)=2, both EC \& CNSS=1. Notwithstanding the non-randomized comparative nature of our study, results suggest that CVC infection rate was reduced significantly after adding doxycycline for prophylaxis. A randomized controlled study is warranted to confirm these findings.

Introduction. Hematopoietic cell transplantation (HCT) is an important and perhaps the only known curative treatment modality for patients with hematologic malignancies and non-malignant hematologic disorders. Patients usually receive highdose of chemotherapy followed by infusion of hematopoietic stem cells either from him/herself or from a related or unrelated donor. As a result, patients 
might experience undesirable side effects including nausea, vomiting, anorexia, diarrhea, and oral mucositis. $^{1-3}$ Moreover, patients' white blood cell counts decrease significantly resulting in impairment of immunity, hence predisposing HCT recipients to infections which might be fatal. Accordingly, prevention of infections is of vital importance in these cases. $^{3-4}$

Hematopoietic stem cells are usually infused through a CVC. At our center, CVCs are inserted upon admission and before the administration of conditioning chemotherapy. Catheter-related bloodstream infections (CR-BSI) are also a recognized and potentially serious complication associated with CVC devices. This is because a CVC can be a vulnerable host for microorganisms to colonize and multiply inducing blood-stream infections. ${ }^{5}$ Prevention of infections associated with CVC is an utmost priority due to its adverse impact on transplant outcomes. The detrimental economic impact of hospital acquired infections transcend to the society at large by potentially resulting in a prohibitive increase in health care costs. Hence, the importance of prevention is emphasized.

Doxycycline, a relatively inexpensive antimicrobial, prescribed at a dose of $100 \mathrm{mg}$ orally twice-daily administered on the day of stem cell infusion, was started on all adult HCT recipients since January 2011 in an attempt to decrease the unusually high rate of CVC-related infections observed at the Bone Marrow Transplantation (BMT) unit of the American University of Beirut Medical Center (AUBMC). We conducted this study to assess the efficacy of doxycycline in reducing CVC infections and compared outcomes against a historic control.

Patients and Methods. This study was approved by the Institutional Review Board of the American University of Beirut. Data was collected retrospectively from the medical records on consecutive HCT patients transplanted between October 2009 and October 2011, who received (doxycycline group) or did not receive doxycycline (comparison group). Patients in the comparison group were transplanted between October 07, 2009 and January 21, 2011; whereas subjects in the doxycycline group underwent their transplantation from January 26, 2011 to October 20, 2011. The selected time period included an almost equal number of patients in both groups. Only adult patients (age $\geq$ 18 years) were eligible for inclusion in this comparative analysis. Collected variables included demographic and patients' characteristic data including age, gender, diagnoses, type of transplant (allogeneic or autologous), and preparative chemotherapy regimens used. In addition, information on CVC site and infection status, isolated microorganisms, and clinical outcomes were also reviewed.

CVCs, mostly inserted via the subclavian vein, were always implanted by a general or vascular surgeon at bedside using local anesthesia and following aseptic techniques. The same caliber antiseptic catheter (Arrow International, Reading, PA, USA) was used, doublelumen for autologous HCT and triple-lumen for allogeneic HCT throughout the study period. All patients received high-dose chemotherapy as part of conditioning, hematopoietic stem cells, and therapeutic support consisting of fluids, medications and/or transfusion of blood products. Irrespective of the doxycycline use to prevent CVC infections, all patients received fluoroquinolone prophylaxis consisting of levofloxacin $500 \mathrm{mg}$ orally daily during severe neutropenia (defined as an absolute neutrophil count (ANC) $<500$ cells $/ \mu \mathrm{L}$ ), later replaced by a third generation cephalosporin, namely cefepime or equivalent, if fever in the setting of neutropenia ensued. The CVC was kept in place for an average of $19 \pm 3$ days prior to its removal. The CVC tip was always be sent for culture according to our standard institutional practice.

Criteria for the diagnosis of CVC infection were defined as follows: (1) a clinical infection with positive blood cultures from the catheter with or without positive peripheral blood cultures; (2) a positive catheter tip culture after removal of the catheter for suspicion of a catheter-related infection. Adult patients who underwent HCT and developed fever within 48 hours after CVC insertion were excluded. This was considered in order to avoid including subjects who could have potentially acquired infection during CVC insertion.

Statistical analysis. Data were analyzed using the Statistical Package for the Social Sciences software version 18.0 (SPSS, Chicago, IL, USA). The continuous study variables were described by their median and range, whereas categorical variables were described by their relative frequencies and counts. Groups were compared for their demographic and clinical variables using chi-square and student $t$ tests. Differences were considered statistically significant if a $\mathrm{p}$ value was less than 0.05 .

Results. Data was collected retrospectively on 54 consecutive patients, 26 in the doxycycline group, and 28 in the comparison group. The median age of patients in the doxycycline and comparison groups were 46 (20-75) years and 41 (23-65) years, respectively $(\mathrm{p}=0.325)$. Groups were also similar for recipient gender $(\mathrm{p}=0.132)$, HCT type $(\mathrm{p}=0.234)$, and number of $\mathrm{CD} 34+$ cells infused at transplantation $(\mathrm{p}=0.223)$ (Table 1). 
Table 1. Patient and treatment characteristics

\begin{tabular}{|c|c|c|c|}
\hline Variables & $\begin{array}{c}\text { Doxycycline- } \\
\text { treated group } \\
(\mathbf{n = 2 6})\end{array}$ & $\begin{array}{c}\text { Comparison } \\
\text { group } \\
(\mathbf{n = 2 8})\end{array}$ & p-value \\
\hline $\begin{array}{c}\text { Median age } \\
\text { (range), years }\end{array}$ & $46(20-75)$ & $41(23-65)$ & 0.325 \\
\hline Gender & $\begin{array}{c}\text { Male }=13 \\
\text { Female }=13\end{array}$ & $\begin{array}{c}\text { Male }=21 \\
\text { Female }=7\end{array}$ & 0.132 \\
\hline Type of HCT & $\begin{array}{c}\text { Autologous=21 } \\
\text { Allogeneic=5 }\end{array}$ & $\begin{array}{c}\text { Autologous=22 } \\
\text { Allogeneic=6 }\end{array}$ & 0.234 \\
\hline $\begin{array}{c}\text { Median CD34 } \\
\text { cells (range), } \\
\text { x10 }\end{array}$ & $8.40(3.71-12.6)$ & $6.30(3.28-13.4)$ & 0.223 \\
\hline
\end{tabular}

HCT . Hematopoietic Stem Cell Transplantation

Neutrophil engraftment kinetics. Addition of doxycycline did not affect time-to-neutrophil engraftment ( 13 days vs. 12 days, $\mathrm{p}=0.164$ ).

Infection rates and associated findings. No (0\%) CVC infection occurred in the doxycycline group, while 5 $(18 \%)$ infection episodes were recorded in 4 patients in the comparison group, resulting in a statistically significant difference $(p<0.001)$. Characteristics of patients who developed CVC are summarized in Table 2. Patients developed high-grade fever requiring a comprehensive work-up including peripheral and central blood culture testing. Subjects had marked leukopenia (and neutropenia) at the time of blood culture testing (ANC $<500$ cells $/ \mu \mathrm{L}$ ) in all cases. The median time from CVC insertion to blood sampling for culture testing was 13.5 (10-21) days. Isolated organisms included Escherichia coli in one patient, coagulase-negative Staphylococcus spp (CNSS) in 2 patients, and both Escherichia coli and CNSS were recovered from the same patient from 2 catheter lumens. Antimicrobial susceptibility testing showed that 3 isolates were resistant to tetracycline, 1 was susceptible, and susceptibility was not available in 1 case. Interestingly, the CVC tip cultures for the abovementioned 4 patients were negative for any bacterial growth.
Discussion. CVCs play an essential role in facilitating essential care to immunocompromised patients requiring treatments such as chemotherapy, blood products, parenteral nutrition, antibiotics and antimicrobial agents. Despite improvements in line care, CVC associated infections remain a serious complication in HCT recipients, particularly during the pre-engraftment phase of the procedure. ${ }^{6-7}$ These infections result in increased morbidity and even death among HCT recipients. ${ }^{8-9}$ Catheter infection generally arises from bacterial colonization of the internal surface of the intravascular catheter. Microorganisms causing CVC infections gain access to the bloodstream through either the skin at the catheter insertion site or through the catheter hub., ${ }^{5,10}$

In HCT patients, all CVCs were required to be inserted following the highest sterile barrier precautions standards.$^{11-12}$ The preferred approach to minimize infections is implementation of the central lineassociated blood-stream infection (CLABSI) bundle, which consists of hand hygiene, full barrier precautions, cleaning the insertion site with chlorhexidine, avoiding femoral sites for insertion and removing unnecessary catheters. ${ }^{13}$ Studies have demonstrated that implementation of CVC care bundle has been associated with a significant reduction in CLABSI. ${ }^{14}$ Although the efficacy of the CLABSI prevention bundle has not been studied in HCT recipients, all five elements of the bundle are commonly recommended for this particular population. As a matter of fact, CLABSI prevention bundle was implemented on all patients (doxycycline and comparison groups) throughout the specified study period.

Other measures to decrease the risk of CVC infections have been studied. Antibiotic- impregnated catheters specifically with minocycline/rifampin have been shown to decrease CLABSI in HCT patients

Table 2. Characteristics of subjects who developed CVC infections

\begin{tabular}{|c|c|c|c|c|c|c|c|}
\hline Age/gender & Disease & $\begin{array}{c}\text { Type of } \\
\text { transplantation }\end{array}$ & $\begin{array}{l}\text { CVC } \\
\text { type }\end{array}$ & $\begin{array}{c}\text { WBC } \\
\times 10^{6} / L^{*}\end{array}$ & $\begin{array}{l}\text { Presence of fever } \\
\text { (temperature in } \\
{ }^{\circ} \mathrm{C} \text { ) }\end{array}$ & $\begin{array}{l}\text { Time from } \\
\text { catheter } \\
\text { insertion to } \\
\text { blood } \\
\text { culture } \\
\text { (days) }\end{array}$ & $\begin{array}{l}\text { Blood culture } \\
\text { growth results }\end{array}$ \\
\hline $36 / \mathrm{M}$ & AML & Allogeneic & $\mathrm{TL}$ & 800 & 38.3 & 21 & $\begin{array}{l}\text { coagulase-negative } \\
\text { Staphylococcus spp. }\end{array}$ \\
\hline $26 / \mathrm{F}$ & $\mathrm{HL}$ & Autologous & DL & 200 & 38.9 & 13 & Escherichia coli \\
\hline $64 / \mathrm{M}$ & NHL & Autologous & DL & 100 & 39.8 & 14 & $\begin{array}{l}\text { coagulase-negative } \\
\text { Staphylococcus spp. } \\
\text { and Escherichia coli }\end{array}$ \\
\hline $61 / \mathrm{M}$ & MM & Autologous & DL & 200 & 38.7 & 10 & $\begin{array}{l}\text { coagulase-negative } \\
\text { Staphylococcus spp. }\end{array}$ \\
\hline
\end{tabular}

Abbreviations: M: male; F: female; AML: acute myelogenous leukemia; HL: Hodgkin lymphoma; NHL: non-Hodgkin lymphoma; MM: multiple myeloma; TL: triple-lumen; DL: double-lumen.

* at time of diagnosing the CVC-related infection. 
requiring subclavian central venous access. ${ }^{15-16}$ In one retrospective study, minocycline/rifampin-impregnated catheters did not affect the susceptibility of staphylococci to tetracyclines or rifampin. ${ }^{15}$ A metaanalysis conducted by Ramritu et al. ${ }^{17}$ for the relative effectiveness of antibiotic-coated CVC, based on five randomized clinical trials in intensive care units, showed a significant reduction in catheter-related blood-stream showed infection associated with the use of these catheters compared to uncoated catheters. ${ }^{17}$

We had observed an unusually high rate of CVCrelated infections at the BMT unit of the AUBMC. As a result, we implemented evidence-based care to ameliorate the situation including abiding by the hand hygiene policy, maximal barrier precautions, proper handling and manipulating of $\mathrm{CVC}$, minimizing handling and maintaining a closed system, limiting manipulation to certified and competent staff, and ensuring aseptic technique during CVC insertion procedures. Moreover, we had already initiated the CLABSI prevention bundle, but without achieving a lower CVC infection rate. The possibility of using antibiotic-coated catheters was entertained. However, this option was not found to be feasible as it would have resulted in a prohibitive increase in the cost of transplantation in Lebanon. We opted instead to initiate all our adult HCT recipients, whether receiving an autologous or an allogeneic HCT, on prophylactic doxycycline at a dose of $100 \mathrm{mg}$ orally twice per day; doxycycline is a broad spectrum antibiotic that is relatively inexpensive and generally well tolerated. Doxycycline has been started at our transplant unit since January 2011 for all adult BMT patients starting on the day of transplant till the day of removing the CVC. Notwithstanding incorporation of doxycycline, we did not change our routine practice of using fluoroquinolone prophylaxis during neutropenia. It is important to emphasize that hematologic and immunologic reconstitution differs between recipients of autografts and allografts; and that administration of antibacterial prophylaxis is not universally applied, especially during autologous HCT.

Interestingly, 3 of the 4 subjects who developed CVC related infections had received autologous HCT. The median (in days) length of hospital stay was similar between subjects in the doxycycline and comparison groups (22 (14-78) days vs. 22 (14-42) days, $\mathrm{p}=0.403$ ), respectively.

One might argue that the use of a broad-spectrum antibiotic could potentially increase the risk of bacterial resistance which represents a serious problem from the medical standpoint. While this argument holds true, one should also consider the serious morbidities and high risk of mortality, resulting from CVC infections in HCT recipients; and their adverse consequences in regards to potential for prolonged hospitalization and consequently increase in cost of health care, among others. Accordingly, it seems obvious that the adverse risks resulting from a serious CVC infection are likely to outweigh the possibility of developing drug resistance by using doxycycline prophylaxis. It is important to keep in mind that bacterial isolates might be resistant to doxycycline as in our case.

Our results are noteworthy, as no CVC infections were observed in the doxycycline group compared to five infections in the historic control group. To our knowledge, there are no published studies that specifically evaluate the use of doxycycline for prevention of CVC infections in the HCT setting. The small size of the groups as well as the small number of events did not allow us to determine the relationship between incidences of CVC infections among various diseases. Nevertheless, this question ought to be addressed in a larger study. Other limitations of our study include the retrospective nature, heterogeneity in regards to diagnoses and type of transplant performed, and conditioning regimens used. The results reported herein shall provide the scientific basis to develop a large randomized multicenter controlled trial to confirm our results.

\section{References:}

1. Bellm LA, Epstein JB, Rose-Ped A, Martin P, Fuchs HJ. Patient reports of complications of bone marrow transplantation. Support Care Cancer. 2000;8: 33-9. PMid:10650895

2. Afessa B, Peters SG. Major complications following hematopoietic stem cell transplantation. Semin Respir Crit Care Med. 2006; 27: 297-309. http://dx.doi.org/10.1055/s-2006945530 PMid:16791762

3. Magauran CE, Salgado CD. Challenges and advances in infection control of hematopoietic stem cell transplant recipients. Infect Disord Drug Targets. 2011; 11: 18-26. http://dx.doi.org/10.2174/187152611794407764

4. Winston DJ. Prophylaxis and treatment of infection in the bone marrow transplant recipient. Curr Clin Top Infect Dis. 1993; 13: 293-321. PMid:8397916

5. Salzman MB, Rubin LG. Intravenous catheter-related infections. Adv Pediatr Infect Dis. 1995; 10: 337-68. PMid:7718211

6. Engelhard D, Akova M, Boeckh MJ, Freifeld A, Sepkowitz K,
Viscoli C, Wade J, Raad I; Center for International Blood and Marrow Transplant Research; National Marrow Donor Program; European Blood and Marrow Transplant Group; American Society of Blood and Marrow Transplantation; Canadian Blood and Marrow Transplant Group; Infectious Disease Society of America; Society for Healthcare Epidemiology of America; Association of Medical Microbiology and Infectious Diseases Canada; Centers for Disease Control and Prevention. Bacterial infection prevention after hematopoietic cell transplantation. Bone Marrow Transplant. 2009; 44: 467-70. http://dx.doi.org/10.1038/bmt.2009.257 PMid:19861980

7. Aksu G, Ruhi MZ, Akan H, Bengisun S, Ustun C, Arslan O, Ozenci $\mathrm{H}$. Aerobic bacterial and fungal infections in peripheral blood stem cell transplants. Bone Marrow Transplant. 2001; 27: 201-5. http://dx.doi.org/10.1038/sj.bmt.1702739 PMid:11281391

8. Rosenthal VD, Guzman S, Migone O, Crnich CJ. The attributable cost, length of hospital stay, and mortality of central 
line-associated bloodstream infection in intensive care departments in Argentina: A prospective, matched analysis. Am J Infect Control. 2003; 31: 475-80. http://dx.doi.org/10.1016/j.ajic.2003.03.002 PMid:14647110

9. Dettenkofer M, Ebner W, Bertz H, Babikir R, Finke J, Frank U, Rüden H, Daschner FD. Surveillance of nosocomial infections in adult recipients of allogeneic and autologous bone marrow and peripheral blood stem-cell transplantation. Bone Marrow Transplant. 2003; 31 ; http://dx.doi.org/10.1038/sj.bmt.1703920 PMid:12732887

10. Salzman MB, Rubin LG. Relevance of the catheter hub as a portal for microorganisms causing catheter-related bloodstream infections. Nutrition. 1997; 13(4 Suppl): 15S-7S. http://dx.doi.org/10.1016/S0899-9007(97)00217-7

11. Raad, II, Hohn DC, Gilbreath BJ, Suleiman N, Hill LA, Bruso PA, Marts K, Mansfield PF, Bodey GP. Prevention of central venous catheter-related infections by using maximal sterile barrier precautions during insertion. Infect Control Hosp Epidemiol. $1994 ; \quad 15(4 \quad \mathrm{Pt} \quad 1)$ : 231-8. http://dx.doi.org/10.1086/646902 PMid:8207189

12. O'Grady NP, Alexander M, Burns LA, Dellinger EP, Garland J, Heard SO, Lipsett PA, Masur H, Mermel LA, Pearson ML, Raad II, Randolph AG, Rupp ME, Saint S; Healthcare Infection Control Practices Advisory Committee (HICPAC). Guidelines for the prevention of intravascular catheter-related infections. Clin Infect Dis. 2011; 52(9): e162-93. http://dx.doi.org/10.1093/cid/cir257 PMid:21460264 PMCid:3106269

13. Pronovost P, Needham D, Berenholtz S, Sinopoli D, Chu H, Cosgrove S, Sexton B, Hyzy R, Welsh R, Roth G, Bander J,
Kepros J, Goeschel C. An intervention to decrease catheterrelated bloodstream infections in the ICU. N Engl J Med. 2006; 355: 2725-32. $\quad$ http://dx.doi.org/10.1056/NEJMoa061115 PMid:17192537

14. Guerin K, Wagner J, Rains K, Bessesen M. Reduction in central line-associated bloodstream infections by implementation of a postinsertion care bundle. Am J Infect Control. 2010; 38: 430-3. http://dx.doi.org/10.1016/j.ajic.2010.03.007 PMid:20570395

15. Chatzinikolaou I, Hanna H, Graviss L, Chaiban G, Perego C, Arbuckle R, Champlin R, Darouiche R, Samonis G, Raad I. Clinical experience with minocycline and rifampin-impregnated central venous catheters in bone marrow transplantation recipients: efficacy and low risk of developing staphylococcal resistance. Infect Control Hosp Epidemiol. 2003; 24: 961-3. http://dx.doi.org/10.1086/502167 PMid:14700414

16. Hanna H, Benjamin R, Chatzinikolaou I, Alakech B, Richardson D, Mansfield P, Dvorak T, Munsell MF, Darouiche R, Kantarjian H, Raad I. Long-term silicone central venous catheters impregnated with minocycline and rifampin decrease rates of catheter-related bloodstream infection in cancer patients: a prospective randomized clinical trial. J Clin Oncol. 2004; 22 : 3163-71. http://dx.doi.org/10.1200/JCO.2004.04.124 PMid: 15284269

17. Ramritu P, Halton K, Collignon P, Cook D, Fraenkel D Battistutta D, Whitby M, Graves N. A systematic review comparing the relative effectiveness of antimicrobial-coated catheters in intensive care units. Am J Infect Control. 2008; 36: 104-17.

PMid: 18313512 http://dx.doi.org/10.1016/j.ajic.2007.02.012 